\title{
HUBUNGAN BAURAN PEMASARAN DENGAN TINGKAT KUNJUNGAN PASIEN UMUM RAWAT JALAN DI RSU ARO PEKALONGAN TAHUN 2020
}

\section{THE CORRELATION MARKETING MIX WITH OUTPATIENT GENERAL VISIT RATE IN RSU ARO PEKALONGAN IN 2020}

\author{
Thalita Devi Astrina ${ }^{1}$, St. Rahmatullah ${ }^{2}$, Nina Zuhana ${ }^{3}$, Wulan Agustin \\ Ningrum $^{4}$ \\ ${ }^{124}$ Farmasi, ${ }^{3}$ Kebidanan, Fakultas Ilmu Kesehatan, Universitas Muhammadiyah Pekajangan \\ Pekalongan \\ Jl. Raya Ambokembang No.08 Pekajangan-Pekalongan \\ Email: thalita.astrina@gmail.com (085786670685)
}

Submitted : 4 April 2021 Reviewed : 16 September 2021 Accepted: 30 September 2021

\begin{abstract}
ABSTRAK
Konsep pemasaran yang dikenal luas dan dikembangkan adalah bauran pemasaran (marketing mix 4P). Bauran pemasaran jasa terdiri dari product, promotion, place dan price. Konsep pemasaran tersebut dipadukan untuk menghasilkan respon yang diinginkan oleh perusahaan (Kotler dan Armstrong, 2008). Sedangkan bauran pemasaran rumah sakit yaitu sekelompok variabel yang bisa dikendalikan serta digunakan oleh rumah sakit untuk mempengaruhi reaksi para pembeli pelayanan (Supriyanto dan Ermawaty, 2010). Tujuan dari penelitian ini adalah untuk mengetahui persepsi pasien umum rawat jalan mengenai bauran pemasaran yang ada di rumah sakit. Jenis penelitian ini penelitian deskriptif analitik dengan pendekatan cross sectional. Populasinya adalah 6.255 dengan sampel penelitian sebanyak 99 responden menggunakan rumus Slovin. Teknik pengambilan sampel yaitu simple random sampling. Data yang digunakan adalah hasil kuesioner yang telah pasien isi. Digunakan analisis univariat dan bivariat yaitu correlation rank spearman. Didapatkan hasil penelitian; (1) bauran pemasaran price lebih dari sebagian persepsi baik yaitu $67.7 \%$ nilai Rho=0.773 menunjukkan hubungan kuat; (2) bauran pemasaran product lebih dari sebagian persepsi baik yaitu $71.7 \%$ nilai $\mathrm{Rho}=0.860$ menunjukkan hubungan sangat kuat; (3) bauran pemasaran promotion lebih dari sebagian persepsi kurang baik yaitu $70.7 \%$ nilai Rho $=0.761$ menunjukkan hubungan kuat; (4) bauran pemasaran place lebih dari sebagian persepsi baik yaitu $74.7 \%$ nilai $\mathrm{Rho}=0.813$ menunjukkan hubungan sangat kuat. Pada tingkat kunjungan pasien lebih dari sebagian peserpsi kurang baik yaitu 65.7\%. Terdapat hasil yang menunjukkan persepsi kurang baik yaitu pada promotion dan tingkat kunjungan pasien. Sehingga diharapkan RSU Aro Pekalongan lebih memperhatikan dan menerapkan dengan baik marketing mix $4 P$ agar tingkat kunjungan pasien dapat meningkat.
\end{abstract}

Kata kunci : Bauran Pemasaran, tingkat kunjungan pasien

\begin{abstract}
As we know, marketing mix is one of the well-known marketing concepts. It consists of product, promotion, place and price. These marketing concepts are combined to produce response the company wants (Kotler and Armstrong, 2008). While the hospital marketing mix is a group of variables that can be controlled and used by the hospital to influence the reactions of service buyers Considering this study is analytical descriptive,
\end{abstract}


it used a cross sectional approach. It took 6.255 people as the population, with taking 99 respondents as the sample. The sample-taken technique used is simple random sampling; by univariate and bivariate analysis as its correlation rank spearman. The result stated as follow; (1) the marketing mix in price is more than good perception, $67.7 \%$ with a Rho value $=0.773$, which means there is a strong correlation; (2) the marketing mix in product is more than good perception, $71.7 \%$ with a Rho value $=0.860$, which shows there is a very strong correlation; (3) the marketing mix in promotion is less than good perception, 70.7\% with a Rho value $=0.761$, which shows a strong correlation; (4) the marketing mix in place is a good perception in most respondents $74.7 \%$ with a Rho value $=0.813$, which shows there is a great correlation both. At the patient visit level, it showed less perception in respondents, $65.7 \%$. In other sides, the poorly perception result has been showed from the aspect of promotion and patients visit level. Thus, it us excepted RSU Aro Pekalongan has more attention and well-applied of marketing mix $4 \mathrm{P}$ to increase the patients visit.

Keywords: Marketing mix, patients visit

\section{Penulis Korespondensi :}

Thalita Devi Astrina

Universitas Muhammadiyah Pekajangan Pekalongan

Jl. Raya Ambokembang No.08 Pekajangan-Pekalongan

Email: thalita.astrina@gmail.com (085786670685)

\section{PENDAHULUAN}

Pelayanan kesehatan adalah pelayanan jasa, jasa berbeda dengan barang. Jika barang merupakan suatu obyek, benda atau alat, maka jasa adalah suatu perbuatan, kinerja. Seseorang tidak dapat menilai hasil dari jasa dari sebelum ia menikmatinya sendiri. Setelah menerima jasa pelayanan kesehatan, kemudian pasien akan membandingkan jasa yang dialami saat di rumah sakit dengan jasa yang diharapkan dari pasien. Jika jasa yang dirasakan tidak sesuai dengan jasa yang diharapkan, maka pasien tidak puas dan akhirnya tidak akan loyal kepada rumah sakit. Tetapi jika jasa yang dirasakan memenuhi atau bahkan melebihi harapan dari pasien maka pasien akan merasa senang dan puas serta tetap bersedia menjalin hubungan jangka panjang dengan rumah sakit dan menjadi pasien yang loyal atau setia kepada rumah sakit (Supriyanto, 2010). Pemasaran di rumah sakit dilaksanakan supaya utilitas rumah sakit menjadi lebih tinggi yaitu dengan cara mempelajari serta memahami perilaku konsumen. Upaya pemenuhan serta harapan pelanggan dapat menciptakan peningkatan jumlah pelanggan bahkan menjadi loyal, sehingga pihak rumah sakit merasa penting untuk melaksanakan pemasaran yaitu dikenal pula dengan konsep bauran pemasaran 4P yaitu product, promotion, place dan price (Kotler dan Armstrong, 2008).

Loyalitas pasien merupakan salah satu inti yang harus diupayakan oleh rumah sakit. Hal ini karena peningkatan loyalitas dari pasien dapat memberikan keuntungan dalam jangka panjang. Bentuk perilaku loyalitas terhadap rumah sakit bermacam-macam seperti menggunakan layanan jasa yang lain dari rumah sakit (general check up, konsultasi kesehatan, pemeriksaan laboratorium, pemeriksaan radiologi, dan lain-lain). Menyampaikan hal-hal yang positif mengenai rumah sakit itu ke pihak lainnya (Hayati,Yuliasfa Sirrul,dkk,2017)

Berdasarkan data kunjungan pasien umum rawat jalan RSU Aro Pekalongan pada bulan Januari hingga Desember tahun 2019 setiap bulannya terkadang mengalami kenaikan dan penurunan, sehingga didapatkan grafik yang tidak stabil. Pada Tribulan I ke Tribulan II mengalami kenaikan kunjungan pasien umum rawat jalan sebesar $2.4 \%$. Pada Tribulan II ke Tribulan III mengalami penurunan sebesar 3.2\%,dan pada Tribulan III ke Tribulan IV mengalami kenaikan sebesar 4.0\% (Data Rawat Jalan RSU Aro Pekalongan, 2019). 
Penurunan jumlah pasien umum rawat jalan ini sangat berdampak pada pendapatan rumah sakit itu sendiri, tentunya hal ini merupakan masalah bagi pihak rumah sakit terutama pada bagian pemasaran yang apabila terdapat penurunan pendapatan rumah sakit maka dapat berdampak pada penurunan pelayanan pasien. Misalnya adanya pengurangan biaya operasional untuk memesan beberapa produk obat, hal ini dapat berdampak kurangnya stok obat atau obat menjadi tidak lengkap dan karena hal tersebut maka pasien akan berpaling ke rumah sakit lainnya yang lebih lengkap persediaan obatnya (Tafdilla, 2016).

\section{METODE PENELITIAN}

Pada penelitian ini digunakan desain penelitian deskriptif analitik yaitu sebuah metode penelitian yang digunakan untuk mendeskripsikan peristiwa yang ada, kemudian dilakukan analisis untuk mengetahui hubungannya dengan pendekatan cross sectional. Pada penelitian ini digunakan instrumen berupa angket atau kuesioner yang ditujukan kepada pasien umum rawat jalan Rumah Sakit Umum (RSU) Aro Kota Pekalongan yang berisi tentang bauran pemasaran (marketing mix 4p) yaitu product, promotion, place dan price yang diterapkan oleh rumah sakit. Kuesioner ini terdiri atas pernyataan positif dan negatif. Kuesioner ini memiliki skala ordinal yaitu dengan jawaban yang bertingkat. Pemberian nilai atau skor dalam masing-masing pernyataan positif adalah 1 untuk tidak setuju, 2 untuk kurang setuju, 3 untuk ragu-ragu, 4 untuk setuju, dan 5 untuk sangat setuju. Sedangkan untuk pemberian nilai atau skor dari pernyataan negatif adalah sebaliknya.

Penelitian ini dilakukan di poli rawat jalan RSU Aro Pekalongan. Sampel yang digunakan adalah pasien umum rawat jalan RSU Aro Pekalongan yang memenuhi dari kriteria inklusi. Teknik pengambilan sampel ini menggunakan simple random sampling. Adapun kriteria tersebut adalah:

a. Kriteria Inklusi

1.Pasien lama yaitu setidaknya pernah melakukan kunjungan ke RSU Aro

Pekalongan sebanyak $2 x$.

2.Bersedia untuk menjadi responden.

3.Pasien dalam kondisi sadar sehingga dapat melakukan pengisian kuesioner dan mampu melakukan komunikasi dengan baik.

4.Berusia minimal 18 tahun.

5.Pasien bisa membaca dan menulis.

\section{b. Kriteria Eksklusi}

1.Pasien merupakan pasien asuransi baik swasta maupun pemerintah.

2.Pasien merupakan pegawai rumah sakit atau keluarganya.

Untuk menentukan besarnya sampel penelitian digunakan rumus Slovin agar dapat menentukan sampel secara tepat dengan jumlah populasi sebanyak 6.255 pasien, maka didapatkan sampel sebanyak:

$$
\begin{aligned}
& \mathrm{n}=\frac{\frac{N}{\left(1+N x d^{3}\right)}}{\mathrm{n}=} \frac{6.255}{\left(1+6.255 x 0.1^{2}\right)} \\
& \mathrm{n}=98,5 \text { atau dibulatkan menjadi } 99
\end{aligned}
$$

\section{Analisis Data}

Data dianalisis univariat dan bivariat yaitu dianalisis menggunakan uji analisis Spearman Rank Order Correlation. Dengan nilai kemaknaan Sig $\leq 0,05$ menggunakan SPSS (Statistical Package for Social Science) dengan tingkat kepercayaan 95\% untuk mengetahui hubungan antara variabel bebas yaitu bauran pemasaran (marketing mix 4p) yaitu product, promotion, place dan price yang diterapkan oleh Rumah Sakit Umum (RSU) Aro Kota Pekalongan dengan variabel terikat yaitu tingkat kunjungan pasien umum rawat jalan. 


\section{HASIL DAN PEMBAHASAN}

\section{Karakteristik Responden}

Gambaran karakteristik responden dianalisis univariat menghasilkan frekuensiserta persentase pada setiap variabel yang berhubungan dengan tingkat kunjungan pasien umum rawat jalan di RSU Aro Pekalongan. Distribusi responden berdasarkan karakteristik seperti pada tabel 1:

Tabel I. Karakteristik Responden

\begin{tabular}{|c|c|c|c|}
\hline No & Karakteristik Responden & Frekuensi & Persentase (\%) \\
\hline \multicolumn{4}{|c|}{ Jenis Kelamin } \\
\hline 1 & Laki-Laki & 54 & $54.5 \%$ \\
\hline 2 & Perempuan & 45 & $45.5 \%$ \\
\hline \multicolumn{4}{|c|}{ Usia } \\
\hline 1 & $18-25$ Tahun & 40 & $40.4 \%$ \\
\hline 2 & $26-35$ Tahun & 25 & $25.3 \%$ \\
\hline 3 & $36-45$ Tahun & 15 & $15.2 \%$ \\
\hline 4 & $46-55$ Tahun & 11 & $11.1 \%$ \\
\hline 5 & $56-65$ Tahun & 8 & $8.1 \%$ \\
\hline
\end{tabular}

Pendidikan Terakhir

\begin{tabular}{lccc}
\hline 1 & Tidak Sekolah & 0 & $0 \%$ \\
\hline 2 & SD & 6 & $6.1 \%$ \\
\hline 3 & SMP & 9 & $9.1 \%$ \\
\hline 4 & SMA & 52 & $52.1 \%$ \\
\hline 5 & D1-D3 & 18 & $18.2 \%$ \\
\hline 6 & S1 & 13 & $13.1 \%$ \\
\hline 7 & Pascasarjana (S2 dan S3) & 1 & $1 \%$ \\
\hline 8 & Lain-Lain & 0 & $0 \%$ \\
\hline
\end{tabular}

Pekerjaan

\begin{tabular}{cccc}
\hline 1 & PNS/TNI/POLRI & 6 & $6.1 \%$ \\
\hline 2 & Karyawan Swasta & 35 & $35.4 \%$ \\
\hline 3 & Wiraswasta & 20 & $20.2 \%$ \\
\hline 4 & Buruh Tani/Nelayan & 8 & $8.1 \%$ \\
\hline 5 & Mahasiswa/Pelajar & 8 & $8.1 \%$ \\
\hline 6 & Lain-Lain & 22 & $22.2 \%$
\end{tabular}

(Data diolah, 2020) 
Berdasarkan tabel I. dapat dilihat bahwa karakteristik responden yang memanfaatkan layanan kesehatan di RSU Aro Pekalongan poli rawat jalan lebih dari sebagian adalah Laki-Laki yaitu sebanyak 54 orang atau jika dalam bentuk persentase adalah $54.5 \%$. Gender merupakan suatu sifat yang mendasar untuk membedakan antara laki-laki dan perempuan yang dilihat dari segi kondisi sosial dan budaya, nilai serta perilaku, mentalitas, emosi, dan faktor-faktor mikrobiologis lainnya. Gender akan mempengaruhi perilaku seseorang dalam memanfaatkan pelayanan produk ataupun jasa (Kusumo, 2016).

Jenis kelamin perempuan itu cenderung dipengaruhi oleh kualitas pelayanan y ang lebih kuat dari penyedia pelayanan jasa ataupun produk tersebut. Sedangkan pada laki-laki lebih dipengaruhi oleh nilai ekonomis (Okoroafo, 2010).

Karakteristik responden berdasarkan umur yaitu hampir setengah dari res ponden penelian adalah mereka dengan usia dewasa muda yaitu memiliki rentang usia 18 - 25 tahun yaitu sebanyak 40 reponden atau jika dalam bentuk persentase adalah $40.4 \%$ dari total sampel penelitian. Berdasarkan hasil penelitian komposisi responden dengan usia dewasa muda yaitu pada rentang 18 - 25 tahun, pada usia tersebut seseorang masih terus berkembang dalam mengambil keputusan untuk memanfaatkan pelayanan kesehatan, hal ini sesuai dengan teori yang menyatakan bahwa kebutuhan dan keinginan konsumen akan berubah seiring dengan perubahan usia dan siklus hidup seseorang (Tafdilla, 2016).

Hal ini didukung pula dari hasil penelitian sebelumnya oleh Tafdilla, 2016 yang menyatakan bahwa karakteristik responden yang memanfaatkan pelayanan kesehatan di poli rawat jalan RSUD Majenang, mayoritas dari responden adalah pasien dengan usia dewasa dini yaitu sebesar 72,5\% dari total responden (Tafdilla, 2016).

Dilihat dari tabel I. karakteristik responden berdasarkan pendidikan pasien yaitu lebih dari sebagian responden dengan pendidikan SMA yaitu sebanyak 52 responden at au jika dalam bentuk persentase adalah sebanyak 52.5\%. Pendidikan seseorang akan mempengaruhi pengetahuan dan keinginan dari seseorang untuk mencari informasi. Tingkat pendidikan merupakan tahapan pendidikan yang telah ditetapkan berdasarkan tingkat perkembangan peserta didik. Untuk meningkatkan kemampuan dari seseorang, diperlukan adanya pendidikan. Dengan adanya pendidikan maka berpengaruh pada saat pengambilan keputusan menjadi tepat dan akurat (Dwijayanthi \& Dharmadiaksa, 2013).

Karakteristik responden berdasarkan pekerjaan hampir setengah pekerjaan dari responden yaitu mempunyai pekerjaan sebagai karyawan swasta yaitu sebanyak 35 responden atau jika dalam bentuk persentase adalah sebanyak $35.4 \%$. Pekerjaan dari seseorang akan mempengaruhi pendapatan dari orang tersebut, hal ini akan mempengaruhi seseorang dalam mengambil keputusan untuk memanfaatkan pelayanan termasuk juga pelayanan kesehatan yang sesuai dengan kemampuannya (Poernomo, 2009).

\section{Variabel Bebas}

Berdasarkan hasil penelitian didapatkan bahwa distribusi reponden mengenai pengaruh bauran pemasaran (marketing mix 4p) dapat dilihat pada tabel dibawah ini :

Tabel II. Distribusi Bauran Pemasaran Price (Harga)

\begin{tabular}{ccccc}
\hline \multirow{2}{*}{ Kategori } & \multicolumn{3}{c}{ Komponen Bauran Pemasaran (Frekuensi dan Persentase) } \\
\cline { 2 - 5 } & Price $($ Harga $)$ & $\begin{array}{c}\text { Product } \\
\text { (produk) }\end{array}$ & $\begin{array}{c}\text { Promotion } \\
\text { (Promosi) }\end{array}$ & $\begin{array}{c}\text { Place } \\
\text { (Tempat) }\end{array}$ \\
\hline $\begin{array}{c}\text { Persepsi Kurang } \\
\text { Baik }(<80.00)\end{array}$ & $32(32.3 \%)$ & $28(28.3 \%)$ & $70(70.7 \%)$ & $25(25.3 \%)$ \\
\hline $\begin{array}{c}\text { Persepsi Baik } \\
(>80.00)\end{array}$ & $67(67.7 \%)$ & $71(71.7 \%)$ & $29(29.3 \%)$ & $74(74.7 \%)$ \\
\hline Total & $99(100.0 \%)$ & $99(100.0 \%)$ & $99(100.0 \%)$ & $99(100.0 \%)$ \\
\hline
\end{tabular}


Berdasarkan tabel II. dapat dilihat bahwa lebih dari sebagian jawaban persepsi baik (>80.00) sebanyak 67 responden dengan persentase $67.7 \%$. Hal ini berarti bauran pemasaran price (harga) RSU Aro Pekalongan sudah baik.

Berdasarkan hasil penelitian didapatkan bahwa distribusi responden mengenai pengaruh bauran pemasaran product (produk) dapat dilihat pada tabel I bahwa lebih dari sebagian jawaban persepsi baik (>80.00) sebanyak 71 responden dengan persentase 71.7\%. Hal ini berarti bauran pemasaran product (produk) RSU Aro Pekalongan sudah baik.

Berdasarkan hasil penelitian didapatkan bahwa distribusi reponden mengenai pengaruh bauran pemasaran promotion (promosi) dapat dilihat pada tabel II bahwa lebih dari sebagian jawaban persepsi kurang baik $(<80.00)$ sebanyak 70 responden dengan persentase $70.7 \%$. Hal ini berarti bauran pemasaran promotion (promosi) RSU Aro Pekalongan kurang baik.

Berdasarkan hasil penelitian didapatkan bahwa distribusi reponden mengenai pengaruh bauran pemasaran place (tempat) dapat dilihat pada tabel II bahwa lebih dari sebagian jawaban persepsi baik (>80.00) sebanyak 74 responden dengan persentase 74.7\%. Hal ini berarti bauran pemasaran place (tempat) RSU Aro Pekalongan sudah baik.

\section{Variabel Terikat}

Berdasarkan hasil penelitian didapatkan bahwa distribusi reponden mengenaitingkat kunjungan pasien umum rawat jalan atau loyalitas di RSU Aro Pekalongan adalah sebagai berikut:

Tabel III. Distribusi Tingkat Kunjungan Pasien Umum Rawat Jalan

\begin{tabular}{lcc}
\hline \multicolumn{1}{c}{ Tingkat Kunjungan Pasien Umum Rawat Jalan } & Frekuensi & $(\%)$ \\
\hline Persepsi Kurang Baik $(<82.00)$ & 65 & 65.7 \\
Persepsi Baik $(>82.00)$ & 34 & 34.3 \\
Total & 99 & 100.0 \\
\hline
\end{tabular}

(Data diolah, 2020)

Berdasarkan tabel IX. dapat dilihat bahwa lebih dari sebagian jawaban persepsi $\mathrm{k} \mathrm{u} \mathrm{rang}$ baik $(<82.00)$ sebanyak 65 responden dengan persentase $65.7 \%$. Hal ini berarti tingkat kunjungan pasien umum rawat jalan RSU Aro Pekalongan ini kurang baik.

\section{Analisis Bivariat}

Hubungan Bauran Pemasaran Price (Harga) RSU Aro Pekalongan terhadap Tingkat Kunjungan Pasien Umum Rawat Jalan Tahun 2020

Untuk mengetahui hubungan bauran pemasaran (marketing mix 4p) RSU Aro Pekalongan dapat dilihat dalam tabel berikut ini

Tabel IV. Tabel Silang Hubungan Bauran Pemasaran (marketing mix 4p) RSU Aro Pekalongan terhadap Tingkat Kunjungan Pasien Umum Rawat Jalan Tahun 2020 


\begin{tabular}{|c|c|c|c|c|c|c|c|c|}
\hline \multirow{3}{*}{$\begin{array}{c}\text { Bauran } \\
\text { Pemasaran } \\
\text { Price }\end{array}$} & \multicolumn{4}{|c|}{ Tingkat Kuniungan Pasien } & \multirow{2}{*}{\multicolumn{2}{|c|}{ Total }} & \multirow{3}{*}{$\begin{array}{c}\text { Rank } \\
\text { Spearman } \\
\text { (Rho) }\end{array}$} & \multirow{3}{*}{$\begin{array}{l}\text { Sig (2 } \\
\text { tailed) }\end{array}$} \\
\hline & \multicolumn{2}{|c|}{ Baik } & \multicolumn{2}{|c|}{ Kurang Baik } & & & & \\
\hline & Frekuensi & $\%$ & Frekuensi & $\%$ & Frekuensi & $\%$ & & \\
\hline Baik & 32 & $\begin{array}{l}47 . \\
8 \%\end{array}$ & 35 & $\begin{array}{c}52.2 \\
\%\end{array}$ & 67 & $\begin{array}{c}100 \\
\%\end{array}$ & 0.773 & 0.000 \\
\hline Kurang Baik & 2 & $\begin{array}{l}6.3 \\
\%\end{array}$ & 30 & $\begin{array}{c}93.8 \\
\%\end{array}$ & 32 & $\begin{array}{c}100 \\
\%\end{array}$ & & \\
\hline Total & 34 & $\begin{array}{l}34 . \\
3 \%\end{array}$ & 65 & $\begin{array}{l}65.7 \\
\%\end{array}$ & 99 & $\begin{array}{c}100 \\
\%\end{array}$ & & \\
\hline Bauran & \multicolumn{4}{|c|}{ Tingkat Kunjungan Pasien } & \multirow{2}{*}{\multicolumn{2}{|c|}{ Total }} & \multirow{3}{*}{$\begin{array}{c}\text { Rank } \\
\text { Spearman } \\
\text { (Rho) }\end{array}$} & \multirow{3}{*}{$\begin{array}{l}\text { Sig (2 } \\
\text { tailed) }\end{array}$} \\
\hline \multirow{2}{*}{$\begin{array}{l}\text { Pemasaran } \\
\text { Product }\end{array}$} & \multicolumn{2}{|c|}{ Baik } & \multicolumn{2}{|c|}{ Kurang Baik } & & & & \\
\hline & Frekuensi & $\%$ & Frekuensi & $\%$ & Frekuensi & $\%$ & & \\
\hline Baik & 34 & $47.9 \%$ & 37 & $52.1 \%$ & 71 & $100 \%$ & 0.860 & 0.000 \\
\hline $\begin{array}{l}\text { Kurang } \\
\text { Baik }\end{array}$ & 0 & $0 \%$ & 28 & $100 \%$ & 28 & $100 \%$ & & \\
\hline Total & 34 & $34.3 \%$ & 65 & $65.7 \%$ & 99 & $100 \%$ & & \\
\hline Bauran & \multicolumn{4}{|c|}{ Tingkat Kunjungan Pasien } & \multirow{2}{*}{\multicolumn{2}{|c|}{ Total }} & \multirow{3}{*}{$\begin{array}{c}\text { Rank } \\
\text { Spearman } \\
\text { (Rho) }\end{array}$} & \multirow{3}{*}{$\begin{array}{l}\text { Sig (2 } \\
\text { tailed) }\end{array}$} \\
\hline Pemasaran & \multicolumn{2}{|c|}{ Baik } & \multicolumn{2}{|c|}{ Kurang Baik } & & & & \\
\hline 'romotion & Frekuensi & $\%$ & Frekuensi & $\%$ & Frekuensi. & $\%$ & & \\
\hline Baik & 25 & $86.2 \%$ & 4 & $13.8 \%$ & 29 & $100 \%$ & 0.761 & 0.000 \\
\hline $\begin{array}{l}\text { Kurang } \\
\text { Baik. }\end{array}$ & 9 & $12.9 \%$ & 61 & $87.1 \%$ & 70 & $100 \%$ & & \\
\hline Total & 34 & $34.3 \%$ & 65 & $65.7 \%$ & 99 & $100 \%$ & & \\
\hline Bauran & \multicolumn{4}{|c|}{ Tingkat Kuniungan Pasien. } & \multirow{2}{*}{\multicolumn{2}{|c|}{ Total }} & \multirow{3}{*}{$\begin{array}{c}\text { Rank } \\
\text { Spearman } \\
\text { (Rho) }\end{array}$} & \multirow{3}{*}{$\begin{array}{l}\text { Sig (2 } \\
\text { tailed) }\end{array}$} \\
\hline Pemasaran. & \multicolumn{2}{|c|}{ Baik } & \multicolumn{2}{|c|}{ Kurang Baik } & & & & \\
\hline Place & Frekuensi & $\%$ & Frekuensi & $\%$ & Frekuensi & $\%$ & & \\
\hline Baik & 34 & $45.9 \%$ & 40 & $54.1 \%$ & 74 & $100 \%$ & 0.813 & 0.000 \\
\hline $\begin{array}{l}\text { Kurang } \\
\text { Baik }\end{array}$ & 0 & $0 \%$ & 25 & $100 \%$ & 25 & $100 \%$ & & \\
\hline Total & 34 & $34.3 \%$ & 65 & $65.7 \%$ & 99 & $100 \%$ & & \\
\hline
\end{tabular}

(Data diolah, 2020)

Berdasarkan tabel IV hasil analisis tabulasi silang mengenai bauran pemasaran price (harga) RSU Aro Pekalongan terhadap tingkat kunjungan pasien ini sudah baik. Penetapan harga yang dilakukan oleh RSU Aro Pekalongan ini pasien yang menjawab bauran pemasaran price (harga) baik adalah sebesar (47.8\%) dan (52.2\%). Konsumen sendiri yang akan memutuskan apakah harga terhadap suatu produk hal ini adalah pelayanan kesehatan sudah tepat. Ketika sebuah perusahaan akan menetapkan harga harus mempertimbangkan persepsi konsumen terhadap harga yang akan ditetapkan dan bagaimana persepsi harga ini akan mempengaruhi konsumen dalam keputusan membeli terhadap suatu produk. Keputusan penetapan harga oleh suatu perusahaan, seperti keputusan bauran pemasaran yang lain harus berorientasi pada pembeli atau konsumen (Kotler dan Keller, 2012).

Hasil analisis bivariat didapatkan nilai Sig $(2$ tailed $)$ sebesar 0.000. Nilai Sig sebesar 0.000 ini lebih kecil dari 0.05 hal ini menunjukkan bahwa H0 ditolak dan Ha diterima yang artinya bahwa adanya hubungan bauran pemasaran price (harga) RSU Aro Pekalongan terhadap tingkat kunjungan pasien umum rawat jalan tahun 2020. Sedangkan hasil dari uji Spearman Rank Order Correlation nilai Rho sebanyak 0.773, untuk nilai adalah sebesar 0.773 yang artinya nilai Rho $>0.50$ dan menurut tabel korelasi Rank Spearman Sugiyono, 2016 nilai Rho 0.773 termasuk kedalam hubungan yang kuat (Sugiyono, 2016).

Berdasarkan tabel IV hasil analisis tabulasi silang mengenai persepsi pasien tentang bauran pemasaran product (produk) RSU Aro Pekalongan terhadap tingkat kunjungan pasien ini sudah baik. Produk merupakan alat yang digunakan dalam pemasaran yang paling dasar. Menurut Kotler dan Amstrong (2008) produk adalah segala sesuatu yang dapat ditawarkan untuk diperhatikan, dimiliki, digunakan atau dikonsumsi yang bisa 
memberikan rasa kepuasan dalam keinginan serta kebutuhan. Sedangkan menurut Rowland dan Rowland produk merupakan jenis pelayanan yang diberikan oleh perusahaan, baik dalam bentuk preventif, diagnostik, terapeutik dan lain- lain. Produk yang ditawarkan oleh RSU Aro ini merupakan segala sesuatu yang dilakukan dalam pelayanan, obat-obatan ataupun proses yang memberikan sejumlah nilai serta manfaat terhadap pasien.

Hasil analisis bivariat didapatkan nilai Sig (2 tailed) sebesar 0.000. Nilai Sig sebesar 0.000 ini lebih kecil dari 0.05 hal ini menunjukkan bahwa H0 ditolak dan Ha diterima yang artinya bahwa adanya hubungan bauran pemasaran product (produk) RSU Aro Pekalongan terhadap tingkat kunjungan pasien umum rawat jalan tahun 2020. Sedangkan hasil dari uji Spearman Rank Order Correlation nilai Rho sebanyak 0.860, untuk nilai adalah sebesar 0.860 yang artinya nilai Rho $>0.50$ dan menurut tabel korelasi Rank Spearman Sugiyono, 2016 nilai Rho 0.860 termasuk kedalam hubungan yang sangat kuat (Sugiyono, 2016).

Berdasarkan hasil analisis tabulasi silang mengenai persepsi pasien tentang bauran pemasaran promotion (promosi) kurang baik yaitu sebesar $70 \%$. Hal ini mungkin karena RSU Aro Pekalongan ini kurang melakukan kegiatan promosi. Promosi merupakan bentuk komunikasi pemasaran, yang berusaha untuk menyebarkan informasi, mempengaruhi maupun membujuk serta mengingatkan pasar sasaran atas perusahaan dan produknya agar bersedia untuk menerima, membeli serta loyal terhadap produk yang ditawarkan oleh perusahaan tersebut. Konsep promosi rumah sakit yaitu bagaimana pasien mengetahui tentang jenis pelayanan yang tersedia di rumah sakit serta bagaimana mereka termotivasi serta puas dengan informasi yang diberikan kemudian pasien menggunakan jasa pelayanan rumah sakit secara berkesinambungan dan pada akhirnya akan menyebarkan informasi tersebut kepada rekan-rekannya (Siragih, 2017).

Hasil analisis bivariat didapatkan nilai Sig (2 tailed) sebesar 0.000. Nilai Sig sebesar 0.000 ini lebih kecil dari 0.05 hal ini menunjukkan bahwa HO ditolak dan Ha diterima yang artinya bahwa adanya hubungan bauran pemasaran promotion (promosi) RSU Aro Pekalongan terhadap tingkat kunjungan pasien umum rawat jalan tahun 2020. Sedangkan hasil dari uji Spearman Rank Order Correlation nilai Rho sebanyak 0.761, untuk nilai adalah sebesar 0.761 yang artinya nilai Rho $>0.50$ dan menurut tabel korelasi Rank Spearman Sugiyono, 2016 nilai Rho 0.761 termasuk kedalam hubungan yang kuat (Sugiyono, 2016).

Berdasarkan hasil analisis tabulasi silang mengenai persepsi pasien tentang bauran pemasaran place (tempat) RSU Aro Pekalongan terhadap tingkat kunjungan pasien ini sudah baik yaitu sebesar $74 \%$. Hal ini bauran pemasaran place (tempat) mencakup lokasi usaha serta pendistribusian produk kepada konsumen. Bauran pemasaran place (tempat) suatu rumah sakit meliputi fasilitas penunjang seperti adanya ATM, tempat ibadah yaitu musholla, kantin, kemudian kemudahan untuk menemukan ruang poliklinik, ruang poliklinik serta ruang tunggu yang nyaman, tempat parkir untuk kendaraan bermotor yang luas serta aman (Tafdilla, 2016).

Hasil analisis bivariat didapatkan nilai Sig $(2$ tailed $)$ sebesar 0.000. Nilai Sig sebesar 0.000 ini lebih kecil dari 0.05 hal ini menunjukkan bahwa H0 ditolak dan Ha diterima yang artinya bahwa adanya hubungan bauran pemasaran place (tempat) RSU Aro Pekalongan terhadap tingkat kunjungan pasien umum rawat jalan tahun 2020. Sedangkan hasil dari uji Spearman Rank Order Correlation nilai Rho sebanyak 0.813, untuk nilai adalah sebesar 0.813 yang artinya nilai Rho $>0.50$ dan menurut tabel korelasi Rank Spearman Sugiyono, 2016 nilai Rho 0.813 termasuk kedalam hubungan yang sangat kuat (Sugiyono, 2016).

\section{KESIMPULAN}

Berdasarkan hasil penelitian dan pembahasan mengenai hubungan bauran pemasaran (marketing mix) RSU Aro Pekalongan terhadap tingkat kunjungan pasien umum rawat jalan tahun 2020 dapat diambil kesimpulan: (1) Adanya hubungan bauran pemasaran price (harga) RSU Aro Pekalongan terhadap tingkat kunjungan pasien umum 
rawat jalan tahun 2020 nilai $\mathrm{Rho}=0.773$ dengan nilai $\mathrm{Sig}=0,000$; (2) Adanya hubungan bauran pemasaran product (produk) RSU Aro Pekalongan terhadap tingkat kunjungan pasien umum rawat jalan tahun 2020 nilai $\mathrm{Rho}=0.860$ dengan nilai Sig $=0,000$; (3) Adanya hubungan bauran pemasaran promotion (promosi) RSU Aro Pekalongan terhadap tingkat kunjungan pasien umum rawat jalan tahun 2020 nilai $\mathrm{Rho}=0.761$ dengan nilai $\mathrm{Sig}=$ 0,000; (4) Adanya hubungan bauran pemasaran place(tempat) RSU Aro Pekalongan terhadap tingkat kunjungan pasien umum rawat jalan tahun 2020 nilai $\mathrm{Rho}=0.813$ dengan nilai $\mathrm{Sig}=0,000$.

\section{UCAPAN TERIMAKASIH}

Peneliti mengucapkan terimakasih kepada BAPPEDA kota Pekalongan, Universitas Muhammadiyah Pekajangan Pekalongan, RSU Aro Pekalongan serta responden pasien umum rawat jalan RSU Aro Pekalongan

\section{DAFTAR PUSTAKA}

Azwar, A. 2010. Pengantar Administrasi Kesehatan. Jakarta: Binapura Aksara.

Dwijayanthi, D. M dan I.B Dharmadiaksa. 2013. Pengaruh Insentif Tingkat Pendidikan, Pelatihan dan Pelatihan Kerja pada Kinerja Individu Pengguna Sistem Informasi Akuntansi SKPD Dispenda Kota Denpasar. E-Journal Akuntansi Universitas Udayana,4(2):332-344.

Hayati, Y. Sirrul, C. Sandra dan Y. T. Herawati. 2018. Hubungan Antara Bauran Pemasaran Dengan Loyalitas Pasien Rawat Jalan Di Rumah Sakit Daerah Kalisat Kabupaten Jember Tahun 2017. Jurnal IKESMA 14(1): 45-56.

Kotler, P dan Keller. 2012. Manajemen Pemasaran Edisi Ke-XII. Jakarta: Erlangga.

Kusumo, M. P. 2016. Pengaruh Faktor Bauran Pemasaran Terhadap Loyalitas Pasien Rawat Inap Rumah Sakit PKU Muhammadiyah Bantul. Jurnal Medicoeticolegal dan Manajemen Rumah Sakit, 5 (2): 107-111.

Okoroafo, S. 2010. General Perspectives of the Export Behavior of Family Business.International Journal of Economics and Finance, 2(3):25-35.

Poernomo, D. I. S. H. 2009. Analisis Pengaruh Persepsi Pasien Tentang Bauran Pemasaran Terhadap Loyalitas Pasien Di Poliklinik Rawat Jalan Rs Baptis Kediri. Tesis. Semarang: Magister Ilmu Kesehatan Masyarakat Undip.

Siragih, M, J. A Pardede dan F. Sijabat. 2017. Faktor-Faktor Bauran Pemasaran yangBerhubungan dengan Kepuasan Pasien. Idea Nursing Journal, 8(2): $1-7$.

Sugiyono. 2016. Metode Penelitian Kuantitatif dan R\&D. Penerbit Alfabeta: Bandung

Supriyanto, S dan Ernawaty. 2010. Pemasaran Industri Jasa Pelayanan Kesehatan. Andi.Yogyakarta.

Tafdilla, A.S. 2016. Pengaruh Persepsi Pasien Tentang Bauran Pemasaran Tehadap Keputusan Pasien Rawat Jalan Memilih Layanan Kesehatan Di Rumah Sakit Umum Daerah Majenang Tahun 2015. Skripsi. Semarang: Fakultas Kesehatan Masyarakat. 
